Reprod. Nutr. Dévelop.,1980, 20 (1 B), 277-286.

\title{
Aldosterone metabolism in pregnant ewes and fetal and newborn lambs
}

\author{
par Michèle MONCAUP *, J. GIRY, J. P. BARLET *, J. LEFAIVRE *, P. DELOST \\ Laboratoire de Physiologie animale, Université de Clermont II \\ BP 45, 63170 Aubière, France \\ * I.N.R.A. Theix 63110 Bequmont, France.
}

\begin{abstract}
Summary. Twenty primiparous Limousine ewes whose fetuses had been chronically catheterized in utero on day 120 of gestation were used. Plasma aldosterone levels were measured by radioimmunoassay during the last 15 days of gestation both in dams and fetuses, and during the first neonatal week in lambs. Aldosterone metabolic clearance rates in dams, fetuses and newborns were determined by continuous infusion of $\left[1,2,6,7-{ }^{3} \mathrm{H}\right]-$ aldosterone. The highest plasma aldosterone levels were observed in dams on days 130 and 142 of gestation, and in fetuses on days 135 and 140 . No correlation was observed between plasma aldosterone and electrolyte levels in the mother, fetus or newborn. Aldosterone metabolic clearance rate decreased between days 142 and 145 in dams and at birth in fetuses of both sexes. No aldosterone transfer could be demonstrated either from dam to fetus or vice-versa.
\end{abstract}

\section{Introduction.}

The ability of the adrenal cortex to secrete aldosterone has been the subject of several investigations in fetal lambs (Wintour ef al., 1975 ; Wintour et al., 1977 ; Brown et al., 1978) and guinea-pigs (Giry and Delost, 1977) and in human cord plasma at term (Katz, Beck and Makowski, 1974 ; Godard, Gaillard and Vallotton, 1976 ; Tochigi Buichi, 1976). However, there are few studies on the metabolism of aldosterone in the pregnant female and the fetus or on the transplacental passage of that hormone (Bayard et $a l ., 1970 a, b$; Giry and Delost, 1979).

The present studies were carried out to determine plasma aldosterone levels and the different parameters of aldosterone metabolism in pregnant ewes and their fetuses over the last 15 days of gestation and in newborn lambs during the first neonatal week. The transplacental passage of this steroid has also been studied.

\section{Material and methods.}

Animals. - Twenty primiparous Limousine ewes of known gestational age, weighing $56 \pm 3 \mathrm{~kg}$ and bearing a single fetus detected by radiography on day 110 
of gestation, were used. The term is $145 \pm 1$ days in this breed, and only ewes lambing on day 145 of pregnancy were included. Five non-pregnant ewes were used as controls. After being at pasture the first 100 days, the pregnant ewes were placed in individual cages on straw-litter where they had free access to water. They were given $1500 \mathrm{~g} / \mathrm{ani}$ mal/day of a graminaceous hay and $400 \mathrm{~g} /$ animal/day of a grain concentrate so that their daily individual intake of sodium and potassium was 2 and $3.5 \mathrm{~g}$, respectively. They were starved for $16 \mathrm{hrs}$ before surgery on day 120 of gestation.

Surgery. - The catheters were implanted in utero according to a method previously described by Barlet ef al. (1978). Briefly, the uterine horn of the pregnant ewe was exposed after laparatomy under halothane anethesia. A $2 \mathrm{~cm}$ incision was made in the uterus in the area of the neck of the fetus. The carotid artery and the jugular vein on one side were isolated and sterile polyvinyl catheters were fitted. Hormonal infusions were carried out through the catheter implanted in the jugular vein, and blood was withdrawn through the catheter implanted in the carotid artery. Each catheter, with a defined volume, was filled with heparinized sterile 0.9 p. $100 \mathrm{NaCl}$, and then passed laterally under the skin, emerging about $30 \mathrm{~cm}$ from the incision which was closed with a nylon suture. About $5 \mathrm{~cm}$ of the catheters protruded from the skin ; this was protected by a bandage fastened around the abdomen.

Blood samples were withdrawn under sterile conditions from the left fetal carotid artery. In this way, the fetal blood could be collected from 9 out of the 20 chronically implanted catheters from day 120 of pregnancy until birth. The mean body birthweight was similar in the 20 cathelerized lambs $(3.2 \pm 0.2 \mathrm{~kg})$ and in the unoperated controls.

Blood samples were obtained in ewes and newborn lambs from a catheter implanted in the left jugular vein. Infusions were given through the right jugular vein.

Experiments. - $\left[1,2,6,7-{ }^{3} \mathrm{H}\right] \mathrm{d}$-aldosterone was infused intravenously through a peristaltic pump at a rate of $0.19 \mu \mathrm{Ci} / \mathrm{min}$ for up to $3 \mathrm{hrs}$ in the ewe to study the parameters of aldosterone metabolism and its possible transplacental passage. $5 \mathrm{ml}$ samples of maternal blood were taken at 60,90,120,135,150,160 and $180 \mathrm{~min}$ after the start of the infusion, and $1 \mathrm{ml}$ of fetal blood was taken ai $90,120,150$ and $180 \mathrm{~min}$ $0.80 \mu \mathrm{Ci} / \mathrm{min}$ of $\left[1,2,6,7-{ }^{3} \mathrm{H}\right] \mathrm{d}$-aldosterone was also infused intravenously in fetal and newborn lambs for up to $3 \mathrm{hrs} .1 \mathrm{ml}$ blood samples were taken from the fetus and the newborn at $60,90,120,150$ and $180 \mathrm{~min}$. To study transplacental passage, $5 \mathrm{ml}$ samples of maternal blood were taken at $90,120,150$ and $180 \mathrm{~min}$. The technique of continuous infusion of radiolabelled hormone was used to assess the aldosterone metabolism parameters of the ewe, fetus and newborn according to a method previously described (Tait, 1963 ; Tait and Burstein, 1964), consisting of carrying a continuous radiolabelled hormone infusion to a steady state. The metabolic clearance rate (MCR) was defined as the ratio of the hormonal infusion rate to the concentration of labelled steroid at steady state. The MCR was expressed in 1/24 hrs or $1 / 24 \mathrm{hrs} / \mathrm{kg}$ body weight. Plasma aldosterone levels, MCR and production rate $(P R)$, defined as MCR $\times$ blood plasma hormone concentration, were measured on days 130,135, 140, 142 and 145 of pregnancy in ewes and their fetuses and at 12, 24, 96 and 168 hrs after birth in newborn lambs. The blood was centrifuged, and the plasma was frozen at $-30^{\circ} \mathrm{C}$. 
Assays.

- Hormones.

a) Plasma aldosferone levels were determined by radioimmunoassay (Bayard et al., 1970b). Thawed plasma samples were extracted with dichloromethane defatted at - $30^{\circ} \mathrm{C}$ with 70 p. 100 methanol and centrifuged. The aldosterone was separated from the cortisol and the cortisone by paper chromatography (Bush $\mathrm{B}_{5}$ ). Recovery, determined by radioactive $\left[1,2-{ }^{3} \mathrm{H}\right]$-aldosterone ( New England Nuclear; SA : $40-$ $60 \mathrm{Ci} / \mathrm{mmole}$ ), was 80 p. 100 . Method sensitivity was $20 \mathrm{pg}$, and precision was 9 p. 100 for 100 to $400 \mathrm{pg}$. The levels were expressed in $\mathrm{ng} / \mathrm{dl}$ of plasma.

b) Plasma labelled aldosterone. After infusion, plasma samples were extracted with dichloromethane. Aldosterone was purified by paper chromatography (Bush $B_{5}$ ). After elution by $9 \mathrm{ml}$ of $\mathrm{CH}_{3} \mathrm{OH}$, the radioactivity of each sample was measured with a liquid scintillation counter (Tricarb, Packard).

- Minerals. Plasma concentrations of sodium and potassium were measured by atomic absorption spectrophotometer (Perkin Elmer 420). The results were expressed as millimoles per liter of plasma (mM). The statistical significance of the results was calculated with Student's $t$ test.

\section{Results.}

Plasma sodium and polassium levels. - Mean plasma $\mathrm{Na}$ levels in non-pregnant controls $(143.1 \pm 8.6 \mathrm{mM})$ were not different from mean values measured in pregnant animals $(146 \pm 1.3 \mathrm{mM})$. In pregnant ewes the levels of $\mathrm{Na}$ rose to $150 \pm 0.9 \mathrm{mM}$ on day $140(0.02<P<0.05)$, then dropped to $143.6 \pm 1.7 \mathrm{mM}$ on day $142(0.005<P<0.01)$ (fig. 1). An increase occurred on the day of lambing $(144.5 \pm 1.2 \mathrm{mM})$ until day 3 post-partum $(151.8 \pm 2.1 \mathrm{mM}) \quad(0.005<P<0.01)$. Plasma $\mathrm{K}$ in non-pregnant controls $(3.8 \pm 0.2 \mathrm{mM})$ was lower than in pregnant animals $(4.4 \pm 0.1 \mathrm{mM})$. In pregnant ewes the levels of $K$ dropped to $4.0 \pm 0.1 \mathrm{mM}$ on day $140(P<0.001)$ and increased on day $145(4.8 \pm 0.4 \mathrm{mM})$ (fig. 1).

In fetuses plasma $\mathrm{Na}$ levels rose from $149 \pm 2 \mathrm{mM}$ on day 140 to $157 \pm 2 \mathrm{mM}$ on day $142(P<0.001)$, then decreased on day $145(148 \pm 4 \mathrm{mM} ; P<0.001)$ (fig. 2$)$. Plasma Na levels in newborns decreased from $151 \pm 2 \mathrm{mM}$ on day 0.5 to $142 \pm 2.7 \mathrm{mM}$ $(P<0.005)$ on day 4. A marked increase in plasma K levels on day $142(5.3 \pm 0.3 \mathrm{mM}$; $P<0.001)$ was followed by a drop on day $145(3.9 \pm 0.1 \mathrm{mM} ; P<0.02)$. Plasma $K$ levels increased from $4.14 \pm 0.05 \mathrm{mM}$ on day 145 of gestation to $5.2 \pm 0.2 \mathrm{mM}$ $(P<0.005) 12$ hrs after birth, then decreased to $4.61 \pm 0.01 \mathrm{mM} 24$ hrs after birth $(P<0.02)$ and remained constant until day 7 .

Plasma aldosterone levels. - Plasma aldosterone levels measured in non-pregnant controls $(24.9 \pm 1.7 \mathrm{ng} / \mathrm{dl})$ were lower than those measured on days 130 and 142 in pregnant animals $(\mathrm{P}<0.001)$ (fig. 1). In pregnant ewes the plasma aldosterone level was high on day 130 of gestation $(77.5 \pm 5.5 \mathrm{ng} / \mathrm{dl})$, decreased on day 135 to $14.6 \pm 0.7 \mathrm{ng} / \mathrm{dl}(\mathrm{P}<0.001)$, remained constant until day $140(16.4 \pm 0.7 \mathrm{ng} / \mathrm{dl})$, rose 
to $(67.1 \pm 4.4 \mathrm{ng} / \mathrm{dl})$ on day $142(\mathrm{P}<0.001)$, and dropped to $22.8 \pm 2.3 \mathrm{ng} / \mathrm{dl}$ $(P<0.001)$ at parturition on day 145 . There were no significant changes in plasma aldosterone concentrations either after lambing (0 hr) or at $72 \mathrm{hrs}$-post-partum (fig. 1).
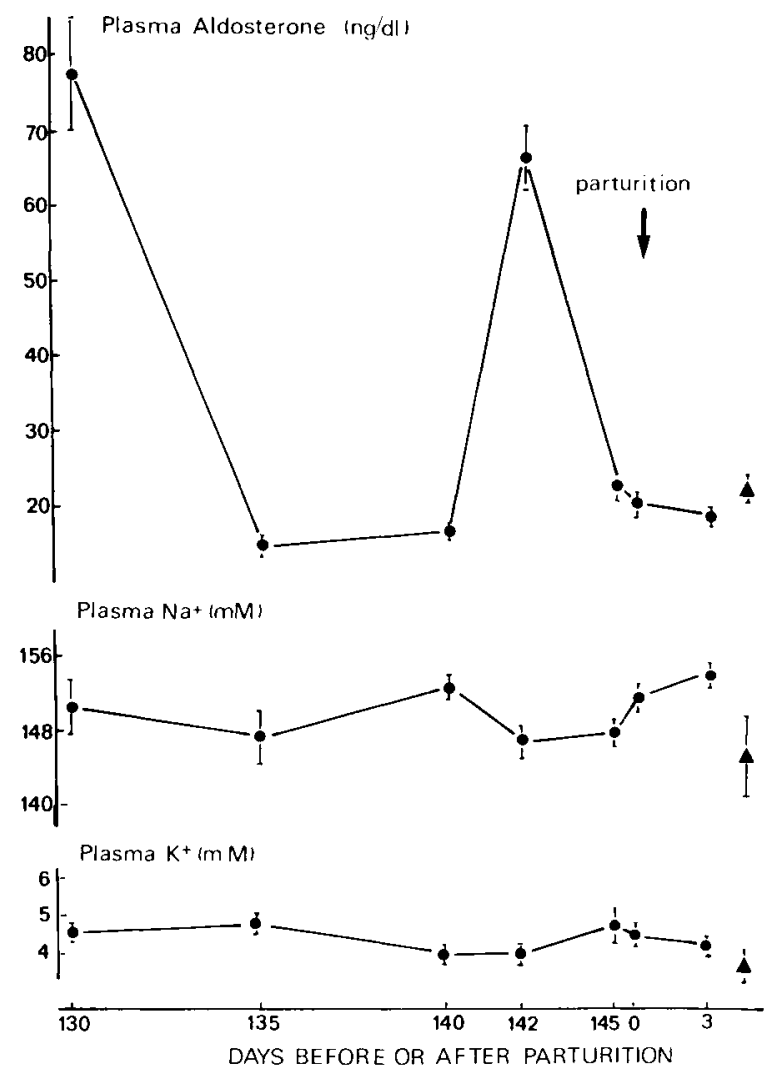

FIG. 1. - Plasma aldosterone, sodium $\mathrm{Na}$ ) and potassium (K) levels in ewes during the 15 days before and the 3 days after parturition (•) (^ non-pregnant non-lactating control ewes) (Mean \pm SEM).

In fetuses plasma aldosterone levels rose from $17.1 \pm 1.0 \mathrm{ng} / \mathrm{dl}$ on day 130 to $38.4 \pm 5.9 \mathrm{ng} / \mathrm{dl}$ on day $140(\mathrm{P}<0.001)$ and decreased to $24.8 \pm 1.34 \mathrm{ng} / \mathrm{dl}(\mathrm{P}<0.01)$ (fig. 2). During a few minutes following delivery $(0 \mathrm{hr})$ plasma aldosterone levels $(29.8 \pm 1.8 \mathrm{ng} / \mathrm{dl})$ were higher $(\mathrm{P}<0.001)$ than those measured on day 130 . They then decreased on day $1(14.6 \pm 2.4 \mathrm{ng} / \mathrm{dl} ; \mathrm{P}<0.001)$ and rose on day $4(20.9 \pm 1.8 \mathrm{ng} / \mathrm{dl}$; $P<0.05$ ).

In fetuses and dams these levels could not be correlated with plasma $\mathrm{Na}$ and $\mathrm{K}$ levels (figs. 1 and 2).

Metabolic Clearance Rate (MCR) of aldosterone. - The infusion of $\left[1,2,6,7-{ }^{3} \mathrm{H}\right]$ aldosterone in ewes, fetuses and neonates did not modify either blood hematocrit or blood plasma electrolyte levels in dams, fetuses or neonates (table 1). In non-pregnant controls the mean value for MCR ( $251 \pm 2191 / 24 \mathrm{hrs})$ was lower than those measured 

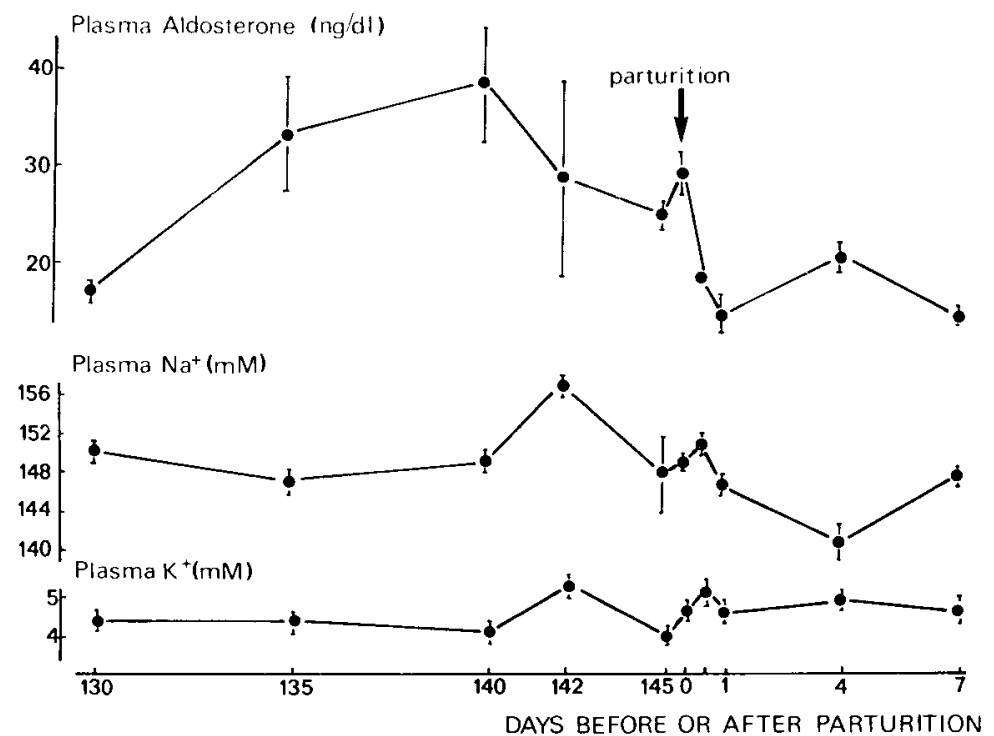

FIG. 2. - Plasma aldosterone, sodium (Na) and potassium (K) levels in lambs during the 15 days before and the 7 days after parfurition (Mean \pm S.E.M.).

\section{TABLE 1}

Hematocrit and plasma electrolyte levels in dams, fetuses and neonates before and after tritiated aldosterone infusion (Mean $\pm S E M ; n=6-10)$. $(B I=$ before tritiated aldosterone infusion ;

$\mathrm{Al}=$ after tritiated aldosterone infusion.)

\begin{tabular}{|c|c|c|c|c|c|c|c|}
\hline \multirow{3}{*}{$\begin{array}{l}\text { Days before } \\
\text { and after } \\
\text { parturition }\end{array}$} & \multirow{3}{*}{ Animals } & \multirow{2}{*}{\multicolumn{2}{|c|}{$\begin{array}{l}\text { Hematocrit } \\
\text { (p. 100) }\end{array}$}} & \multicolumn{4}{|c|}{ Plasma electrolytes (mM) } \\
\hline & & & & \multicolumn{2}{|c|}{$\mathrm{Na}^{+}$} & \multicolumn{2}{|c|}{$K^{+}$} \\
\hline & & $\mathrm{BI}$ & Al & $\mathrm{BI}$ & Al & BI & Al \\
\hline 130 & $\begin{array}{l}\text { Dams } \\
\text { Fetuses }\end{array}$ & $\begin{array}{l}30.6 \pm 1.3 \\
36.8 \pm 1.4\end{array}$ & $\begin{array}{l}30.6 \pm 1.3 \\
37.6 \pm 0.7\end{array}$ & $\begin{array}{l}140.6 \pm 1.7 \\
151.6 \pm 2.7\end{array}$ & $\begin{array}{l}142.5 \pm 1.0 \\
150.6 \pm 1.9\end{array}$ & $\begin{array}{l}3.8 \pm 0.2 \\
4.4 \pm 0.2\end{array}$ & $\begin{array}{l}3.7 \pm 0.2 \\
4.3 \pm 0.2\end{array}$ \\
\hline 135 & $\begin{array}{l}\text { Dams } \\
\text { Fefuses }\end{array}$ & $\begin{array}{l}30.5 \pm 1.0 \\
38.6 \pm 0.4\end{array}$ & $\begin{array}{l}31.0 \pm 1.3 \\
38.3 \pm 0.3\end{array}$ & $\begin{array}{l}168.6 \pm 5.0 \\
149.6 \pm 1.8\end{array}$ & $\begin{array}{r}166.1 \pm 4.9 \\
149.1 \pm 2.2\end{array}$ & $\begin{array}{l}4.4 \pm 0.1 \\
4.5 \pm 0.1\end{array}$ & $\begin{array}{l}4.4 \pm 0.2 \\
4.3 \pm 0.1\end{array}$ \\
\hline 140 & $\begin{array}{l}\text { Dams } \\
\text { Fetuses }\end{array}$ & $\begin{array}{l}31.0 \pm 0.6 \\
38.9 \pm 0.4\end{array}$ & $\begin{array}{l}31.5 \pm 0.9 \\
39.4 \pm 0.4\end{array}$ & $\begin{array}{l}146.6 \pm 5.2 \\
147.0 \pm 3.0\end{array}$ & $\begin{array}{l}153.6 \pm 8.8 \\
145.0 \pm 3.5\end{array}$ & $\begin{array}{l}4.1 \pm 0.2 \\
4.1 \pm 0.1\end{array}$ & $\begin{array}{l}3.9 \pm 0.2 \\
4.1 \pm 0.1\end{array}$ \\
\hline 142 & $\begin{array}{l}\text { Dams } \\
\text { Fetuses }\end{array}$ & $\begin{array}{l}30.0 \pm 1.2 \\
33.0 \pm 1.2\end{array}$ & $\begin{array}{l}31.0 \pm 1.0 \\
33.7 \pm 0.8\end{array}$ & $\begin{array}{l}168.3 \pm 7.2 \\
148.2 \pm 1.5\end{array}$ & $\begin{array}{l}166.7 \pm 7.6 \\
148.5 \pm 1.4\end{array}$ & $\begin{array}{l}3.9 \pm 0.2 \\
4.2 \pm 0.1\end{array}$ & $\begin{array}{l}4.1 \pm 0.2 \\
4.4 \pm 0.2\end{array}$ \\
\hline 145 & $\begin{array}{l}\text { Dams } \\
\text { Fetuses }\end{array}$ & $\begin{array}{l}32.0 \pm 1.2 \\
36.3 \pm 1.8 \\
\end{array}$ & $\begin{array}{l}32.8 \pm 1.5 \\
37.0 \pm 1.2\end{array}$ & $\begin{array}{l}142.2 \pm 1.9 \\
141.0 \pm 2.4\end{array}$ & $\begin{array}{l}140.8 \pm 3.4 \\
144.8 \pm 1.5 \\
\end{array}$ & $\begin{array}{l}4.0 \pm 0.2 \\
3.9 \pm 0.1\end{array}$ & $\begin{array}{l}3.9 \pm 0.1 \\
4.2 \pm 0.1 \\
\end{array}$ \\
\hline $\begin{array}{c}0.5 \\
1 \\
3 \\
4 \\
7\end{array}$ & $\begin{array}{l}\text { Newborns } \\
\text { Newborns } \\
\text { Dams } \\
\text { Newborns } \\
\text { Newborns }\end{array}$ & $\begin{array}{l}32.3 \pm 1.3 \\
34.0 \pm 0.3 \\
35.0 \pm 1.0 \\
37.6 \pm 0.8 \\
30.3 \pm 1.7\end{array}$ & $\begin{array}{l}33.7 \pm 1.0 \\
34.6 \pm 0.8 \\
35.0 \pm 1.0 \\
38.0 \pm 0.7 \\
30.3 \pm 1.7\end{array}$ & $\begin{array}{l}144.0 \pm 1.3 \\
146 \pm 3.3 \\
145.4 \pm 3.3 \\
145.0 \pm 2.0 \\
150.0 \pm 1.0\end{array}$ & $\begin{array}{l}147.0 \pm 3.0 \\
149.0 \pm 3.0 \\
148.5 \pm 0.9 \\
144.0 \pm 1.0 \\
154.0 \pm 3.0\end{array}$ & $\begin{array}{l}3.9 \pm 0.3 \\
3.7 \pm 0.1 \\
4.4 \pm 0.1 \\
4.0 \pm 0.1 \\
4.5 \pm 0.2\end{array}$ & $\begin{array}{l}4.1 \pm 0.2 \\
3.7 \pm 0.1 \\
3.9 \pm 0.2 \\
3.9 \pm 0.2 \\
4.5 \pm 0.2\end{array}$ \\
\hline
\end{tabular}


in dams on day $140(P<0.02)$ of gestation and 3 days post-partum $(0.02<P<0.05)$ (fig. 3). In pregnant ewes, MCR did not vary significantly between days 130 and 142 of gestation (respectively $2247 \pm 321$ and $2693 \pm 96 \mathrm{l} / 24 \mathrm{hrs}$ ); it then fell to $2097 \pm 172 \mathrm{l} / 24 \mathrm{hrs}$ on day $145(\mathrm{P}<0.001)$ and increased to $2935 \pm 43 \mathrm{l} / 24 \mathrm{hrs}$ on day 3 post-partum.

In fetal and newborn lambs MCR (1/24 hrs) decreased on day $140(560 \pm 191 / 24 \mathrm{hrs})$ and increased to $696 \pm 28 \mathrm{l} / 24 \mathrm{hrs}$ on day 145 (fig. 3). Birth (time 0 ) was associated with a marked fall of MCR $(457 \pm 18 \mathrm{I} / 24 \mathrm{hrs})$ which rose to $609 \pm 44 \mathrm{l} / 24 \mathrm{hrs}$ on the first neonatal day, remained constant until day 4 , and increased to $995 \pm 30 \mathrm{l} / 24 \mathrm{hrs}$ on day 7.

Aldosterone production rate (PR). - In pregnant ewes during the last 15 days of pregnancy and the beginning of lactation, PR showed two elevated values on days 130 and $142(1740.3 \pm 249$ and $1657.5 \pm 100 \mu \mathrm{g} / 24 \mathrm{hrs}$, respectively) which were higher
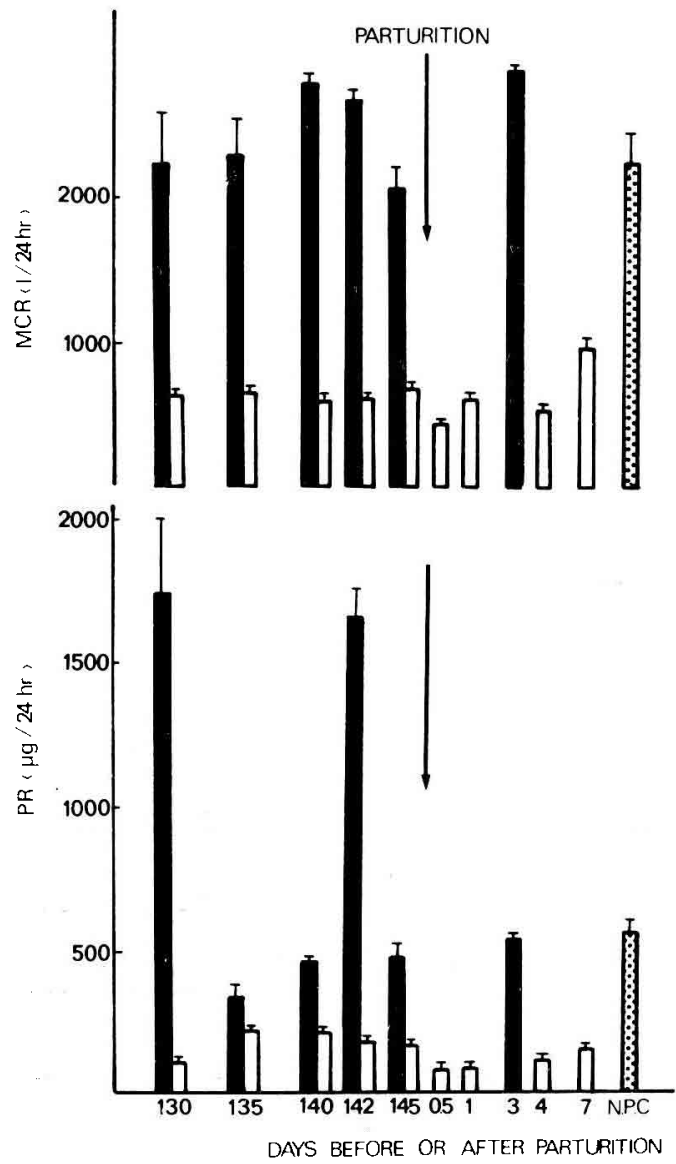

FIG. 3. - Aldasterone metabolic clearance rate (MCR) and production rate (PR) in ewes (black bars) and their lambs (white bars) during the 15 days before and the 7 days following parturition (Mean \& SEM) (dotted bars (N.P.C.) : non-pregnant non-lactating control ewes). 
than those measured in non-pregnant controls $(560 \pm 55 \mu \mathrm{g} / 24 \mathrm{hrs})$. PR did not vary significantly at parturition or during 3 days post-partum (fig. 3 ).

A significant rise in PR occurred on day 135 in fetuses $(219.4 \pm 2.3 \mu \mathrm{g} / 24 \mathrm{hrs}$; $P<0.001)$ (fig. 3$)$; this level fell on day $142(181 \pm 2.5 \mu \mathrm{g} / 24 \mathrm{hrs} ; \mathrm{P}<0.001)$ until the first neonatal day $(89.5 \pm 6.4 \mu \mathrm{g} / 24 \mathrm{hrs} ; \mathrm{P}<0.001)$. An increase was seen from day $4(113.1 \pm 2.6 \mu \mathrm{g} / 24 \mathrm{hrs} ; \mathrm{P}<0.01)$ to day $7(153.1 \pm 4.7 \mu \mathrm{g} / 24 \mathrm{hrs} ; \mathrm{P}<0.001)$.

Transplacental passage of aldosterone. - We failed to detect any labelled aldosterone in the fetal plasma when $\left[1,2,6,7-{ }^{3} \mathrm{H}\right]$-aldosterone was infused in the ewe on days $130,135,140,142$ or 145 of pregnancy but we found labelled tetrahydro-aldosterone (THA).

Fetal plasma THA levels did not show any correlation with the duration of pregnancy. When $\left[1,2,6,7-{ }^{3} \mathrm{H}\right]$ - aldosterone was infused in the fetus at the same times of gestation, no radiolabelled aldosterone could be found in maternal blood plasma ; only labelled THA was detected.

\section{Discussion.}

A number of workers have found that plasma sodium levels in the fetus were lower than in the mother (Barnes, 1976). In our experimental conditions, as in recent reports on ovines (Mellor, 1970 ; Liggins et al., 1973 ; Broughton Pipkin et al., 1974a) and cattle (Wilson et al., 1977), sodium and potassium concentrations were similar in maternal and fetal plasmas (figs. 1 and 2).

The differences concerning plasma aldosterone values (Wintour ef al., 1976 ; Boulfekhar, 1978) might result from a breed factor or from differences in the assays. Although breed effect on plasma aldosterone levels has not been reported, plasma aldosterone was isolated in Tadmit ewes by thin-layer and paper chromatographies (Boulfekhar, 1978) ; we used only paper chromatography for our plasma aldosterone measurement. Furthermore, $\mathrm{Na}$ and $\mathrm{K}$ intake greatly influences plasma aldosterone levels in sheep (Blair-West ef al., 1963). There are no data on $\mathrm{Na}$ and $\mathrm{K}$ intake in Tadmit ewes (Boulfekhar, 1978), although plasma $\mathrm{Na}$ and $\mathrm{K}$ levels did not vary significantly during the experimental period (Boulfekhar, 1978). We followed the recommendations of Gueguen (1978) as to daily $\mathrm{Na}$ and $\mathrm{K}$ supply for pregnant ewes. An increase of plasma renin and angiotensin levels and the competitive inhibition of aldosterone by progesterone in the kidney might be the main factors responsible for a rise in the plasma aldosterone levels. Plasma renin levels are higher in pregnant ewes than in controls but do not seem to vary between 110 and 144 days of pregnancy (Broughton Pipkin ef al., 1974b). Progesterone levels in the blood of pregnant sheep are only 2 to 5 times higher than those found during the peak of the estrous cycle (Bedford ef al., 1972 ; Liggins et al., 1973, 1977) ; such a level may be insufficient to act as a significant competitive inhibitor of aldosterone (Wintour et al., 1977).

One major question is : are aldosterone levels in fetal plasma predominantly of fetal adrenal origin? Transplacental aldosterone passage probably contributes significantly to the circulating level in the human (Bayard et al., 1970a) and the guinea-pig (Giry and Delost, 1979) fetus, but our results show that in sheep aldosterone transfer from the mother to the fetus (and vice-versa) is negligible. This species difference could 
be easily related to divergencies in placental structure. We could not correlate plasma $\mathrm{Na}$ and $\mathrm{K}$ levels with plasma aldosterone levels in dams, fetuses and neonates (figs. 1 and 2).

In our experimental conditions, PR variations were similar to those of the plasma aldosterone levels (figs. 1, 2, 3). Aldosterone PR does not accurately reflect aldosterone adrenal secretion since it also includes the peripheral metabolism of that hormone. The peripheral blood levels of the aldosterone measured in sheep fetuses (Wintour et al., 1975 ; Brown et al., 1978) in utero are lower than those of our experiments (mean aldosterone level in fetal blood plasma : $28.3 \pm 5.5 \mathrm{ng} / \mathrm{dl}$; fig. 2). Nevertheless, the increase in fetal plasma aldosterone which we observed between days 130 and 140 (120 p. 100 ; fig. 2) was very similar to the 100 p. 100 increase reported at the same stages by Brown ef al. (1978). Furthermore, in human cord plasma aldosterone levels varying from $17.2 \pm 9.5 \mathrm{ng} / 100 \mathrm{ml}$ (Bayard and Boulard, 1973) to $163 \pm 67 \mathrm{ng} / 100 \mathrm{ml}$ Katz, Beck and Makowski, 1974 ; Godard, Gaillard and Vallotton, 1976) have already been reported. The slight increase in plasma aldosterone levels measured in newborn lambs immediately after birth (fig. 2) might be related to the high concentration of angiotensin Il-like activity (Broughton Pipkin et al., 1974b). According to Alexander et al. (1968), aldosterone secretion rate (measured in the left adrenal venous plasma of exteriorized fetuses) increases considerably just before term and after birth.

To our knowledge, aldosterone MCR and PR have not been reported in sheep. The mean MCR value ( $2419 \pm 154$ l/24 hrs) was higher in our experiments during the last 15 days of pregnancy than that reported in women during the last week of pregnancy $(1543 \pm 113 \mathrm{l} / 24 \mathrm{hrs})$ (Tait ef al., 1962) or at the end of labor (1 $783 \pm 517 \mathrm{l} / 24 \mathrm{hrs}$ ) (Bayard et al., 1970a). Aldosterone MCR in pregnant ewes also appears to be higher than cortisol MCR which was determined in similar conditions (Paterson and Harrisson, 1968). As in dams, aldosterone MCR in fetuses was higher than cortisol MCR (about 124 I/24 hrs) (Beitins et al., 1970 ; Dixon ef al., 1970 ; Liggins ef al., 1973). The most striking result on aldosterone MCR was its abrupt decrease at the time of parturition (fig. 3) ; at that time, obturation of the ductus venosus (connecting the inferior vena cava and the umbilical vein during fetal life) removes the placental compartment from fetal circulation, and might be responsible for the MCR decrease.

Our results in pregnant ewes demonstrate a decrease in aldosterone metabolism during the last 3 days of gestation, characterized by low plasma aldosterone levels and MCR.

The highest fetal plasma aldosterone level was found on day 140 of gestation. Aldosterone MCR did not vary significantly during the last 15 days of intrauterine life or during the first neonatal week, except at the time of delivery when an abrupt decrease in aldosterone MCR was observed. In our experimental conditions, no aldosterone transfer could be demonstrated either from dam to fetus or vice-versa.

5e Réunion du groupe Déyeloppement I.N.R.A., Clermont-Ferrand/Theix, 17-18 mai 1979.

Résumé. Une vingtaine d'agnelles de race Limousine dont les fœtus sont cathétérisés chroniquement in utero à 120 jours de gestation furent utilisées. L'aldostéronémie a été mesurée par radio-immunologie pendant les 15 derniers jours de gestation à la fois chez les brebis et leurs fotus, ef pendant la première semaine après la naissance pour les agneaux. 
Le taux de clearance métabolique (T.C.M.) de l'aldostérone chez les brebis, les fœtus et les nouveau-nés a été déterminé par perfusion continue d'aldostérone quadruplement marquée $\left(\left[1,2,6,7-{ }^{3} \mathrm{H}\right]\right.$-aldostérone). Les taux plasmatiques d'aldostérone les plus élevés se rencontrent chez les brebis aux $130^{\mathrm{e}}$ et $142^{\mathrm{e}}$ jours de gestation, tandis que chez les foetus on les observe aux $135 \mathrm{e}, 140 \mathrm{e}$ jours ante partum et à la naissance. Le taux de clearance métabolique diminue entre le $140^{\mathrm{e}}$ et le $145^{\mathrm{e}}$ jour de gestation chez les brebis, et à la naissance chez les fœtus. Nous n'avons observé aucune corrélation entre aldostéronémie et kaliémie ou natrémie, aussi bien chez la mère que chez le fœtus ou le nouveau-né. Aucun transfert de l'aldostérone de la mère au fœetus ou du fœetus à la mère n'a pu être mis en évidence dans notre étude.

\section{References}

ALEXANDER D. P., BRITTON H. G., JAMES V. H. T., NIXON D. A., PARKER R. A., WINTOUR E. M. WRIGHT R. D., 1968. Steroid secretion by the adrenal gland of foetal and neonatal sheep. J. Endocrinol., 40, 1-13.

BARLET J. P., DAVICCO M. J., LEFAIVRE J., GAREL J. M., 1978. Endocrine regulation of plasma phosphate in chronically sheep fetuses with catheters implanted in utero, 243-256. In MASSRY S. G., Homeostasis of phosphate and other minerals, Plenum Publ. Co, New York.

BARNES R. J., 1976. Water and mineral exchange between maternal and fetal fluids, 194-214. In BEARD R. W., NATHANIELZ P. N., Fetal physiology and medicine, W. B. Saunders Ltd, Philadelphia.

BAYARD F., ANCES I. G., TAPPER A. J., WELDON V. V., KOWARSKI A., MIGEON C. J., $1970 a$. Transplacental passage and foetal secretion of aldosterone. J. clin. Invest., 49, 1389-1393.

BAYARD F., BEITINS J. Z., KOWARSKI A., MIGEON C. J., 1970b. Measurement of plasma aldosterone by radioimmunoassay. J. clin. Endocr. Metab., 31, 1-6.

BAYARD F., BOULARD C., 1973. La sécrétion d'aldostérone chez le foetus ef le nouveau-né, 35-42. In Hormones ef régulations métaboliques, Masson ef Cie, Paris.

BEDFORD C. A., CHALLIS J. R. G., HARISSON F. A., HEAP R. B., 1972. The role of oestrogens and progesterone in the onset of parturition in various species. J. Reprod. Fert., suppl. 16, 1-23.

BEITINS I. Z., KOWARSKI A., SHERMETA D. W., DE LEMOS R. A., MIGEON C. J., 1970. Fetal and maternal secretion rate of cortisol in sheep : Diffusion resistance of placenta. Pediat. Res., 4, 129-134.

BLAIR-WEST J. R., COGHLAN J. P., DENTON D. A., GODING J. R., MUNRO J. A., WRIGHT R. D., 1963. The reduction of the pressor action of angiotensin II in sodium deficient conscious sheep. Austr. J. exp. Biol. med. Sci., 41, 369-376.

BOULFEKHAR L., 1978. Evolutions de la progestéronémie, cortisolémie, aldostéronémie el de l'électrolytémie au cours de la gestation ef de la parturition chez la brebis de race Tadmit. Th. $3^{\mathrm{e}}$ cycle, Alger, $149 \mathrm{Pp}$.

BROUGHTON PIPKIN F., LUMBERS E. R., MOTT J. C., 1974a. Factors influencing plasma renin and angiotensin II in the conscious pregnant ewe and its foetus. J. Physiol. London, 243, 619-636.

BROUGHTON PIPKIN F., LUMBERS E. R., MOTT J. C., KIRPATRICK S. M. L., $1974 b$. Renin and angiotensin-like levels in foetal newborn and adult sheep. J. Physiol. London, 241, 575-588.

BROWN E. H., COGHLAN J. P., HARDY K. J., WINTOUR E. M., 1978. Aldosterone, corticosterone, cortisol, 11 deoxycortisol and 11 deoxycorticosterone concentrations in the blood of chronically cannulated ovine fetuses : effect of ACTH. Acta endocrinol., 88, 364-374.

DIXON R., HYMAN A., GURPIDE E., DYRENFURTH I., COHEN H., BOWE E., ENGEL T., DANIEL S., JAMES S., VANDE WIELE R., 1970. Feto-maternal transfer and production of cortisol in the sheep. Steroids, 16, 771-789.

GIRY J., DELOST P., 1977. Changes in the concentrations of aldosterone in the plasma and adrenal glands of the foetus, the newborn and the pregnant guinea-pig during the perinatal period. Acta endocrinol., 84, 133-141.

GIRY J., DELOST P., 1979. Transplacental transfer of aldosterone in the guinea-pig during late pregnancy. J. Steroid Bioch., 10, 541-547.

GODARD C., GAILLARD R., VALLOTTON M. B., 1976. The renin angiotensin aldosterone system in mother and fetus at term. Nephron, 17, 353-360. 
GUEGUEN L., 1978. Minéraux, 161-176. In JARRIGE R., Principes de la nutrition et de l'alimentation des ruminants, I.N.R.A. Publ.

KATZ F. H., BECK P., MAKOWSKI E. L., 1974. The renin-aldosterone system in mother and fetus at term. Am. J. Obstet. Gynecol., 118, 51-55.

LIGGINS G. C., FAIRCLOUGH R. J., GRIEVES S. A., FORSTER C. S., KNOX B. S., 1977. Parturition in the sheep, 5-30. In KNIGHT J., O'CONNOR M., The fetus and birth, Ciba Found. Symp. 47, Exerpta med., Amsterdam.

LIGGINS G. C., FAIRLOUGH R. J., GRIEVES S. A., KENDALL J. Z., KNOX B. S., 1973. The mechanism of initiation of parturition in the ewe. Recent Progr. Horm. Res., 29, 111-148.

MELLOR D. J., 1970. Distributions of ions and electrical potential differences between mother and foetus at different gestational ages in goats and sheep. J. Physiol., London, 207, 133-150.

PA.TERSON J. Y. F., HARRISSON F. A., 1968. The specific activity of plasma cortisol in sheep after intravenous infusion of $1,2-{ }^{3} \mathrm{H}_{2}$ cortisol, and its relation to the distribution of cortisol. $J$. Endocrinol., 40, 37-47.

TAIT J. F., 1963. Review : the use of isotopic steroids for measurement of production rates in vivo. J. clin. Endocr. Metab., 23, 1285-1297.

TAIT J. F., BURSTEIN S., 1964. In vivo studies of steroid dynamics in man, 441-557. In PINCUS G., THIMANN K. V., ASTWOOD E. B., Hormones, New York Acad. Press.

TAIT J. F., LITTLE B., TAIT S. A. S., FLOOD C., 1962. The metabolic clearance rate of aldosterone in pregnant and non pregnant subjects estimed by both single-injection and constant infusion methods. J. clin. Invest., 41, 2093-2100.

TOCHIGI BUICHI, 1976. Studies on aldosterone concentrations of maternal, fetal and neonatal plasma during pregnancy. Nichidai Igaku Zasshi, 35, 857-868.

WILSON G. D. A., HUNTER J. T., DERRICK G. H., AITKEN W. M., KRONFELD D. S., 1977. Fetal and maternal plasma electrolytes blood gases and $\mathrm{pH}$ in dairy cows during late gestation. $J$. Dairy Sci., 60, 1110-1116.

WINTOUR E. M., BLAIR-WEST J. R., BROWN E. H., COGHLAN J. P., DENTON D. A., NELSON J., ODDIE C. J., SCOGGINS R. A., WHIPP G. T., WRIGHT R. D., 1976. The effect of pregnancy on mineral and glucocorticoid secretion in the sheep. Clin. Exp. Pharm. Physiol., 3, $331-342$.

WINTOUR E. M., BROWN E. H., DENTON D. A., HARDY K. J., Mc DOUGALL J. C., ODDIE C. J., WHIPP G. T., 1975. The ontogeny and regulation of corticosteroid secretion by the ovine foetal adrenal. Acta endocrinol., 79, 301-316.

WINTOUR E. M., BROWN E. H., DENTON D. A., HARDY K. J., MC DOUGALL J. C., ROBINSON P. M., ROWE E. J., WHIPP G. T., 1977. In vifro and in vivo adrenal cortical steroid production by fetal sheep : effect of angiotensin II, sodium deficiency, ACTH. Res. Steroids, 7, 567-573. 